\title{
A Regular Study on Yarn Count, Size Box Temperature and Machine Speed to Increase Weaving Efficiency of Cotton Fabric
}

\author{
Umme Magreba Takebira, A. T. M. Mohibullah* (D, Md. Zawadul Hossain, Shajidul Islam Tanim, \\ Md. Sharif Ahammad Redoy, Md. Lutfar Rahman, Md. Shakib Rejwan
}

Department of Apparel Manufacturing \& Technology, BGMEA University of Fashion \& Technology, Dhaka, Bangladesh

Email: *mohib@buft.edu.bd

How to cite this paper: Takebira, U.M., Mohibullah, A.T.M., Hossain, Md.Z., Tanim, S.I., Redoy, Md.S.A., Rahman, Md.L. and Rejwan, Md.S. (2020) A Regular Study on Yarn Count, Size Box Temperature and Machine Speed to Increase Weaving Efficiency of Cotton Fabric. Journal of Textile Science and Technology, 6, 168-176. https://doi.org/10.4236/jtst.2020.64014

Received: March 9, 2020

Accepted: November 1, 2020

Published: November 4, 2020

Copyright $\odot 2020$ by author(s) and Scientific Research Publishing Inc. This work is licensed under the Creative Commons Attribution International License (CC BY 4.0).

http://creativecommons.org/licenses/by/4.0/

\begin{abstract}
Sizing is an inherent part of weaving works, consisting in the coating of the warp yarn with a polymeric adhesive, such as starch, in order to assist efficient weaving. The study is aimed to assess the effects of squeezed roller pressure, dryer temperature, yarn count, machine speed (rpm) on cotton fabric weaving. Coarser and finer cotton yarn samples were prepared using sizing solution BENSIZE 850. Different size box temperature, yarn count, fabric construction, machine speed, squeeze roller pressure were considered to construct different weaving designs to study yarn breakages parameter. A warping plan was designed on TAROKO V5.4 (190325) software. The results established that size box lower temperature and higher machine speed provide the smallest amount yarn break during weaving for coarser cotton yarn and the highest for finer cotton yarn. Size box higher temperature and lower machine speed provide maximum yarn breakage during weaving coarser cotton yarn and minimum for fine yarn. Size penetration is uniform, which provides a higher strength of the yarn to less breakage. This aspect of the research suggested that higher yarn strength gives a lesser amount of breakage.
\end{abstract}

\section{Keywords}

Sizing Material, Machine Parameters, Different Counts, Sizing Efficiency

\section{Introduction}

Woven fabrics are the ancient and most aristocratic means of wearing and sizing that is a mandatory process for warp yarn before weaving in order to increase the strength of the yarn. The warp yarn is required to go through the sizing 
process with a protective coating to increase yarn strength by various ingredients to increase the weave ability of the fabric. Weaving efficiency depends on the sizing parameters such as squeeze roller pressure, size box temperature, machine speed, yarn count, size materials, take-up percentage, viscosity, dryer temperature, substantial content percentage, total ends. Main sizing ingredients are starch, PVA, CMC. Starch is used extensively either alone or in blend with other sizing agents. It is found widely in plants and seeds (such as wheat, corn, rice), or the roots (potato, tapioca), or the pith or plants of the stem (sago). The primary function is to bind, adhesive, stiffen the yarn [1]. Polyvinyl alcohol (PVA), a principal sizing agent, is used for polyester and its blends. It shares about $30 \%$ global market of textile sizes [2]. Different sizing factor during weaving develops numerous impacts. Three different count cotton yarns were collected to study the effect of the sizing parameters on fabric construction. Samples were arranged using a sizing solution BENSIZE 850. Different size box temperature, yarn count, fabric construction, machine speed, squeeze roller pressure were considered to construct different weaving designs to study yarn breakages parameter. The study was projected yarn breakage and analyzed its parameter during sizing and weaving. Squeezing pressure plays a vital role in applying uniform coating of size paste, the amount of sized material absorbed by the yarn will depend on the squeeze roller pressure. It varies depending on the count of the warp yarn. Size box temperature is the temperature of sized liquor, which varies according to yarn count and size material wise. Usually, the temperature of the size box is $90^{\circ} \mathrm{C}$, and this temperature is changed depending upon yarn count, size material, total ends, etc. Machine Speed (RPM) is a significant factor in sizing which varies depending on the yarn count. Incorrect machine speed can lead to improper sizing, which damages yarn quality. Yarn count is a numerical value, which determines fineness or coarseness of fiber, yarn, fabric. Lower count yarn requires higher size liquor and vice versa. The study shows the effect of controllable parameters on sizing efficiencies, such as squeezed roller pressure, size box temperature, machine speed, yarn coarseness and fineness.

\section{Literature Review}

Seminal contributions have been made in a previous study which revealed that more considerable yarn elongate loss higher extensibility of the yarn. The average extensibility of the sized yarn reduces below an absolute minimum, and the less extensible portions were estimated to break during waving [3]. Turukmane has also explored it in prior studies; the sized warp beams ensure maximum efficiency in weaving. Combination size boxes with and without pre-setting device ensure short yarn paths. Cylinder dried in various arrangements guarantees a rapid and gentle drying of the yarn [4]. Several theories have been proposed to yarn quality that generally increases by size, some focusing on changing in braking force, elongation at break and abrasion resistance by sizing does not de- 
pend only on the sizing conditions, but also on the yarn properties before sizing. In addition to the braking force, which is very important in the weaving process, it is necessary to emphasize that elongation at break, abrasion resistance, etc. Others on yarn breakage largely depend on the fiber and yarn properties, and on the conditions of processing the yarn for weaving [5]. Some authors have also suggested that sizing machine parameters squeezing pressure, machine speed and yarn stretch, the wear ability of the machine increased with improved production and efficiency [6]. The National Bureau of Standards, in cooperation with the Alabama Polytechnic Institute, had examined the consequence of sizing cotton yarn with the white-potato starch generally used for this purpose [7]. A more comprehensive description can be found in sizing that was termed as the "Heart of Weaving". Sizing is applied into the yarn mainly to improve the weave ability of warp yarn by making it more resistant to the action of weaving, i.e. absorption, friction, tension \& flexing [8]. It also maintains good fabric quality by reducing hairiness, weakness \& by increasing smoothness, the absorbency of yarn. The most other features of the sizing are the change of various physical properties.

\section{Materials and Method}

Different sizing parameters during weaving expound several impacts. 100\% Cotton $20 \mathrm{Ne}, 40 \mathrm{Ne}$ and $60 \mathrm{Ne}$ count yarns were collected from the local market of Bangladesh for fabric construction. Samples were prepared using a sizing solution BENSIZE 850. Different size box temperature, yarn count, fabric construction, machine speed, squeeze roller pressure was considered to construct different weaving design to study yarn breakages parameter. The study was estimated yarn breakage and analyzed its parameter during sizing and weaving. The investigation of sizing performance and the experiments were completed at CCI Sampling Laboratory, and Fabric Structure and Design Laboratory of SHANTEX (PVT) Ltd. CCI mini warper, sample loom and sizing machine were used to analysis sizing performance of the woven fabric.

Table 1 and Figure 1 shows the sample fabrics specifications. The yarn was conditioned and sized with a suitable sizing solution; in that case, BENSIZE 850 chemical was used. A warping plan was designed on TAROKO V5.4 (190325) software of sample warper, for 11-inch width, and weaver's beam was produced with the sized yarn. The weaver's beam was then loaded on the drawing and denting frame.

The drawing was done in 1, 2, 3, 4 and 1, 2, 3, 4, 5, 6 sequences. After the drawing, denting was done. Drawn and the dented beam was then construction on loom and weaving was started. There was constant observation during the weaving process, and broken warp ends were mended. Weave construction was changed after every 5 inches; the breakage rate was different for each construction. Table 2 presented yarn breakage test parameters and experimental condition consisting of size box temperature, yarn count, fabric construction, 
Table 1. Weaving construction of sample fabric.

\begin{tabular}{cccc}
\hline Basic Fabric Construction & Construction $_{1}$ & Construction $_{2}$ & Construction $_{3}$ \\
\hline$\frac{\text { Warp Count } \times \text { Weft Count }}{\text { Ends Per Inch } \times \text { Picks Per Inch }}$ & $\frac{20 \times 20}{90 \times 70}$ & $\frac{40 \times 30}{90 \times 74}$ & $\frac{60 \times 40}{110 \times 90}$ \\
\hline
\end{tabular}
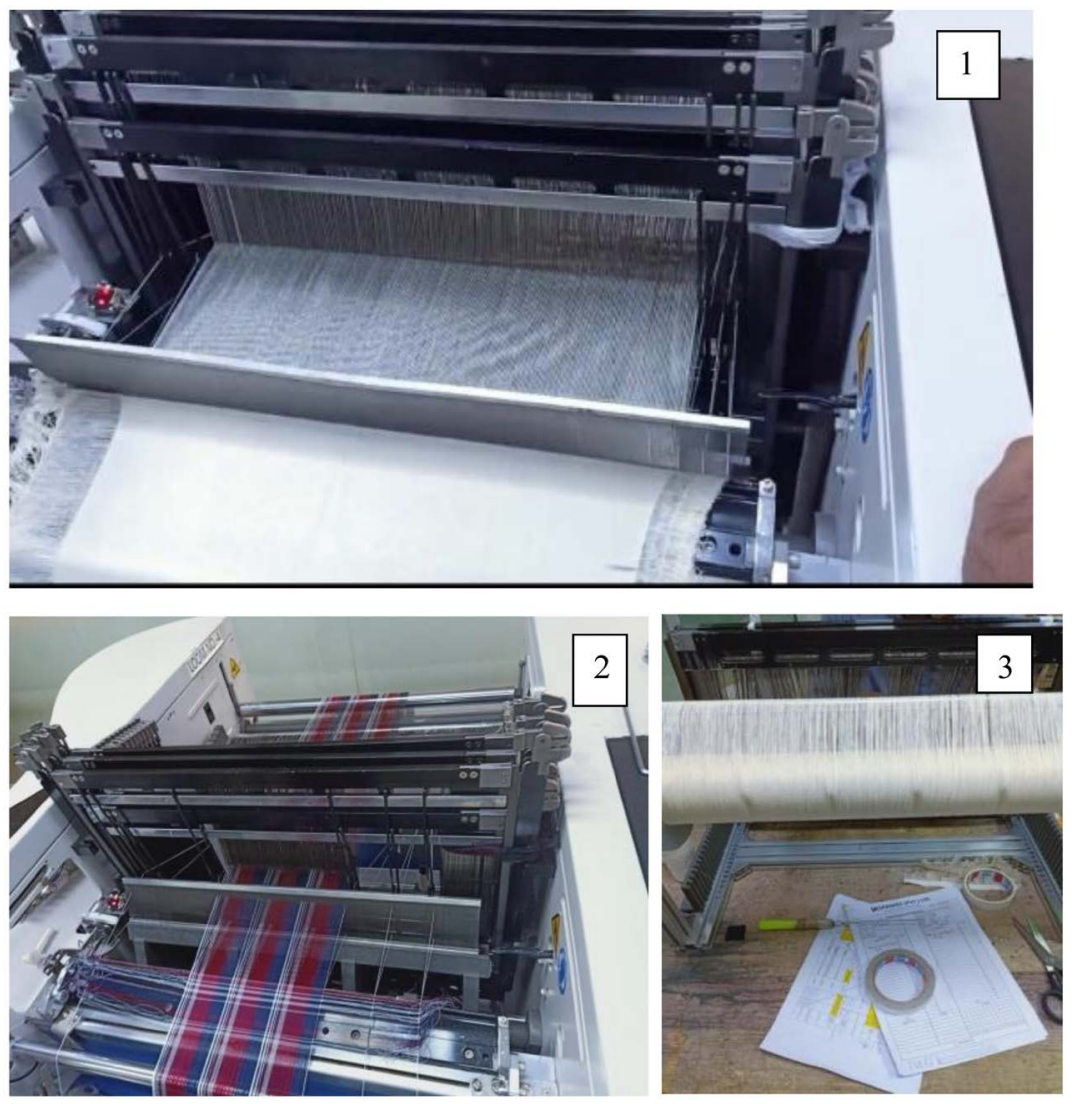

Figure 1. Warping plan on TAROKO V5.4 (190325).

machine speed, squeeze roller pressure.

\section{Result and Discussion}

Ten different weaving constructions were used; the weaving design was randomly chosen and given in the CCI loom machine using software TAROKO V5.4 (190325) where size box temperature was $95^{\circ} \mathrm{C}$ and $100^{\circ} \mathrm{C}$, machine speed $180 \mathrm{rpm}$ and 120-rpm yarn count $20 \mathrm{Ne}$. Table 3 presents the weaving construction for yarn count $20 \mathrm{Ne}$.

Constructions were changed after 5 inches successively maintaining time, during weaving in Table 3. Yarn breakages averages were estimated, allowing for $95^{\circ} \mathrm{C}$ and $100^{\circ} \mathrm{C}$ size box temperature for weaving at $180 \mathrm{rpm}$ and $120 \mathrm{rpm}$ machine speed.

In the second experiment, here also ten different weaving constructions were used shown in Table 4; weaving design were in addition randomly chosen and given in the same loom machine via software TAROKO V5.4 (190325) where 
Table 2. Yarn breakage test parameters.

\begin{tabular}{|c|c|c|c|c|c|c|}
\hline Yarn Breakage Test for & \multicolumn{2}{|c|}{$\begin{array}{l}\text { Construction } \\
\text { Experiment-1 }\end{array}$} & \multicolumn{2}{|c|}{$\begin{array}{c}\text { Construction } \\
\text { Experiment-2 }\end{array}$} & \multicolumn{2}{|c|}{$\begin{array}{l}\text { Construction } \\
\text { Experiment-3 }\end{array}$} \\
\hline Sample Size (inch) & \multicolumn{2}{|c|}{$60 \times 11$} & \multicolumn{2}{|c|}{$60 \times 11$} & \multicolumn{2}{|c|}{$60 \times 11$} \\
\hline No. of Weave Construction & \multicolumn{2}{|c|}{10} & \multicolumn{2}{|c|}{10} & \multicolumn{2}{|c|}{10} \\
\hline \multicolumn{7}{|l|}{ Sizing Parameters } \\
\hline Size box Temperature & $95^{\circ} \mathrm{C}$ & $100^{\circ} \mathrm{C}$ & $90^{\circ} \mathrm{C}$ & $95^{\circ} \mathrm{C}$ & $80^{\circ} \mathrm{C}$ & $85^{\circ} \mathrm{C}$ \\
\hline Machine Speed & $180 \mathrm{rpm}$ & $120 \mathrm{rpm}$ & $250 \mathrm{rpm}$ & $200 \mathrm{rpm}$ & $200 \mathrm{rpm}$ & $220 \mathrm{rpm}$ \\
\hline Yarn Count & \multicolumn{2}{|c|}{20} & \multicolumn{2}{|c|}{40} & \multicolumn{2}{|c|}{60} \\
\hline Squeeze roller Pressure & \multicolumn{2}{|c|}{$0.5 \mathrm{bar}$} & \multicolumn{2}{|c|}{$0.5 \mathrm{bar}$} & \multicolumn{2}{|c|}{$0.5 \mathrm{bar}$} \\
\hline
\end{tabular}

Chemical (BENSIZE 850) 7.5\% per $100 \mathrm{ml}$ water $7.5 \%$ per $100 \mathrm{ml}$ water $7.5 \%$ per $100 \mathrm{ml}$ water

Table 3. Weaving construction for yarn count $20 \mathrm{Ne}$.

\begin{tabular}{|c|c|c|c|c|c|c|}
\hline \multirow{3}{*}{$\begin{array}{l}\text { Serial } \\
\text { No. }\end{array}$} & \multirow{3}{*}{$\begin{array}{l}\text { Weave Construction for } \\
\text { yarn count } 20 \mathrm{Ne}\end{array}$} & $\begin{array}{c}\text { yarn } \\
\text { breakage }\end{array}$ & $\begin{array}{c}\text { yarn } \\
\text { breakage }\end{array}$ & $\begin{array}{c}\text { yarn } \\
\text { breakage }\end{array}$ & $\begin{array}{c}\text { yarn } \\
\text { breakage }\end{array}$ & \multirow[t]{2}{*}{$\begin{array}{c}\text { Image of yarn } \\
\text { breakage for } 20 \mathrm{Ne}\end{array}$} \\
\hline & & $95^{\circ} \mathrm{C}$ & $95^{\circ} \mathrm{C}$ & $100^{\circ} \mathrm{C}$ & $100^{\circ} \mathrm{C}$ & \\
\hline & & $180 \mathrm{rpm}$ & $120 \mathrm{rpm}$ & $180 \mathrm{rpm}$ & $120 \mathrm{rpm}$ & \\
\hline a & Plain & 2 & 2 & 2 & 2 & \\
\hline $\mathrm{b}$ & $\frac{4}{2} \mathrm{Z}$ Twill & 0 & 0 & 0 & 0 & \\
\hline c & $\frac{4}{2} \mathrm{~S}$ Twill & 1 & 1 & 0 & 1 & \\
\hline d & $\frac{3}{3} \mathrm{Z}$ Twill & 0 & 0 & 1 & 1 & \\
\hline e & $\frac{3}{3} \mathrm{~S}$ Twill & 2 & 2 & 2 & 2 & \\
\hline $\mathrm{f}$ & Mockleno & 1 & 2 & 2 & 2 & \\
\hline g & Ordinary Honeycomb & 0 & 0 & 0 & 0 & \\
\hline $\mathrm{h}$ & $\frac{1}{3} \mathrm{Z}$ Broken Weft Twill & 1 & 1 & 1 & 1 & \\
\hline $\mathrm{i}$ & $\frac{1}{5}$ Irregular Sateen & 0 & 0 & 0 & 1 & \\
\hline $\mathrm{j}$ & $\frac{5}{1}$ Irregular Sateen & 1 & 2 & 2 & 2 & \\
\hline & Total & 8 & 10 & 10 & 12 & \\
\hline
\end{tabular}

size box temperature was $90^{\circ} \mathrm{C}$ and $95^{\circ} \mathrm{C}$, machine speed $250 \mathrm{rpm}$ and 200 rpm, yarn count $40 \mathrm{Ne}$. Constructions were changed after 5 inches successively maintaining time, during weaving for ten different weaving structure. The average of yarn breakages was estimated after three comprehensive weaving experiments were completed, and the total was estimated in Table 4 .

In the third experiment Table 5, for yarn count $60 \mathrm{Ne}$; ten different weaving constructions were used; weaving design were besides randomly chosen and given in the same loom machine via similar software where size box temperature was $85^{\circ} \mathrm{C}$ and $80^{\circ} \mathrm{C}$, machine speed $220 \mathrm{rpm}$ and $200 \mathrm{rpm}$. Constructions were 
Table 4. Weaving construction for yarn count $40 \mathrm{Ne}$.

\begin{tabular}{|c|c|c|c|c|c|c|}
\hline \multirow[t]{2}{*}{ Serial No. } & \multirow[t]{2}{*}{$\begin{array}{l}\text { Weave Construction } \\
\text { for yarn count } 40 \mathrm{Ne}\end{array}$} & $\begin{array}{c}\text { yarn } \\
\text { breakage }\end{array}$ & $\begin{array}{c}\begin{array}{c}\text { yarn } \\
\text { breakage }\end{array} \\
90^{\circ} \mathrm{C}\end{array}$ & $\begin{array}{c}\begin{array}{c}\text { yarn } \\
\text { breakage }\end{array} \\
95^{\circ} \mathrm{C}\end{array}$ & $\begin{array}{c}\begin{array}{c}\text { yarn } \\
\text { breakage }\end{array} \\
95^{\circ} \mathrm{C}\end{array}$ & \multirow{2}{*}{$\begin{array}{l}\text { Image of yarn breakage } \\
\text { for } 40 \mathrm{Ne}\end{array}$} \\
\hline & & $200 \mathrm{rpm}$ & $250 \mathrm{rpm}$ & $200 \mathrm{rpm}$ & $250 \mathrm{rpm}$ & \\
\hline a & Plain & 3 & 3 & 3 & 3 & \\
\hline $\mathrm{b}$ & $\frac{1}{1}$ Oxford & 2 & 2 & 2 & 2 & \\
\hline c & $\frac{2}{2} \mathrm{Z}$ Twill & 3 & 2 & 3 & 3 & \\
\hline d & $\frac{2}{2} \mathrm{~S}$ Twill & 0 & 0 & 1 & 0 & \\
\hline $\mathrm{e}$ & $\frac{1}{1}$ Matt & 2 & 2 & 2 & 2 & \\
\hline $\mathrm{f}$ & $\frac{3}{1} \mathrm{Z}$ Twill & 2 & 2 & 2 & 2 & +12 is \\
\hline g & $\frac{3}{1} \mathrm{~S}$ Twill & 1 & 1 & 2 & 1 & raves \\
\hline $\mathrm{h}$ & $\frac{1}{5} \mathrm{Z}$ Twill & 1 & 0 & 1 & 1 & \\
\hline i & $\frac{3}{1}$ Irregular Satin & 1 & 1 & 2 & 2 & \\
\hline $\mathrm{j}$ & $\frac{3}{1}$ Irregular Satin & 2 & 2 & 3 & 3 & \\
\hline & Total & 17 & 15 & 21 & 19 & \\
\hline
\end{tabular}

Table 5. Weaving construction for yarn count $60 \mathrm{Ne}$.

\begin{tabular}{|c|c|c|c|c|c|c|c|}
\hline \multirow{3}{*}{\multicolumn{2}{|c|}{ Serial No. }} & & $\begin{array}{c}\text { yarn } \\
\text { breakage }\end{array}$ & $\begin{array}{c}\text { yarn } \\
\text { breakage }\end{array}$ & $\begin{array}{c}\text { yarn } \\
\text { breakage }\end{array}$ & $\begin{array}{c}\text { yarn } \\
\text { breakage }\end{array}$ & \multirow[t]{3}{*}{$\begin{array}{c}\text { Image of yarn } \\
\text { breakage for } 60 \mathrm{Ne}\end{array}$} \\
\hline & & & $80^{\circ} \mathrm{C}$ & $80^{\circ} \mathrm{C}$ & $85^{\circ} \mathrm{C}$ & $85^{\circ} \mathrm{C}$ & \\
\hline & & & $200 \mathrm{rpm}$ & $220 \mathrm{rpm}$ & $200 \mathrm{rpm}$ & $220 \mathrm{rpm}$ & \\
\hline $\mathrm{a}$ & \multicolumn{2}{|c|}{ Plain } & 4 & 5 & 3 & 3 & \\
\hline $\mathrm{b}$ & $\frac{1}{1}$ & Oxford & 2 & 2 & 2 & 2 & \\
\hline c & $\frac{2}{2}$ & Z Twill & 3 & 3 & 3 & 3 & \\
\hline d & $\frac{2}{2}$ & S Twill & 2 & 2 & 2 & 2 & 3 \\
\hline $\mathrm{e}$ & $\frac{1}{1}$ & Matt & 4 & 4 & 3 & 3 & \\
\hline $\mathrm{f}$ & $\frac{3}{1}$ & Z Twill & 2 & 2 & 2 & 2 & \\
\hline g & $\frac{3}{1}$ & S Twill & 4 & 4 & 3 & 4 & \\
\hline $\mathrm{h}$ & $\frac{1}{5}$ & Z Twill & 3 & 3 & 2 & 3 & \\
\hline $\mathrm{i}$ & $\frac{3}{1}$ & Irregular Satin & 2 & 3 & 2 & 2 & \\
\hline \multirow{2}{*}{\multicolumn{2}{|c|}{ j }} & Irregular Satin & 4 & 4 & 3 & 3 & \\
\hline & & Total & 30 & 32 & 25 & 27 & \\
\hline
\end{tabular}


changed after 5 inches successively maintaining time, during weaving. The average of yarn breakages was estimated after three comprehensive weaving experiments were completed for each condition.

We describe the results of yarn breakage number, which show the different result for a different condition in Figure $2 \&$ Figure 3 . This is an essential finding in the understanding of the parameters of yarn breakage during weaving. The present study confirmed the findings of size box temperature and machine speed, which play a vital role during weaving. Another promising finding was that size box higher temperature and lower machine speed provides maximum yarn break during weaving for $20 \& 40 \mathrm{Ne}$ count cotton yarn. Our results also demonstrated that size box lower temperature and higher machine speed provides least amount yarn break during weaving for same count cotton yarn. Together, the present findings confirm that size box lower temperature and lower machine speed condition and size box higher temperature and higher machine speed condition provide average yarn break during weaving for that identical yarn count.

Figure 4 shows the results of the experiment found clear support that size box lesser temperature and higher machine speed provides maximum yarn break during weaving for $60 \mathrm{Ne}$ count cotton yarn. This analysis found evidence for that the size box more temperature and less machine speed provides least amount yarn break during weaving for same count cotton yarn. From the results, it is clear that size box lower temperature and lower machine speed condition and size box higher temperature and higher machine speed condition provide average yarn

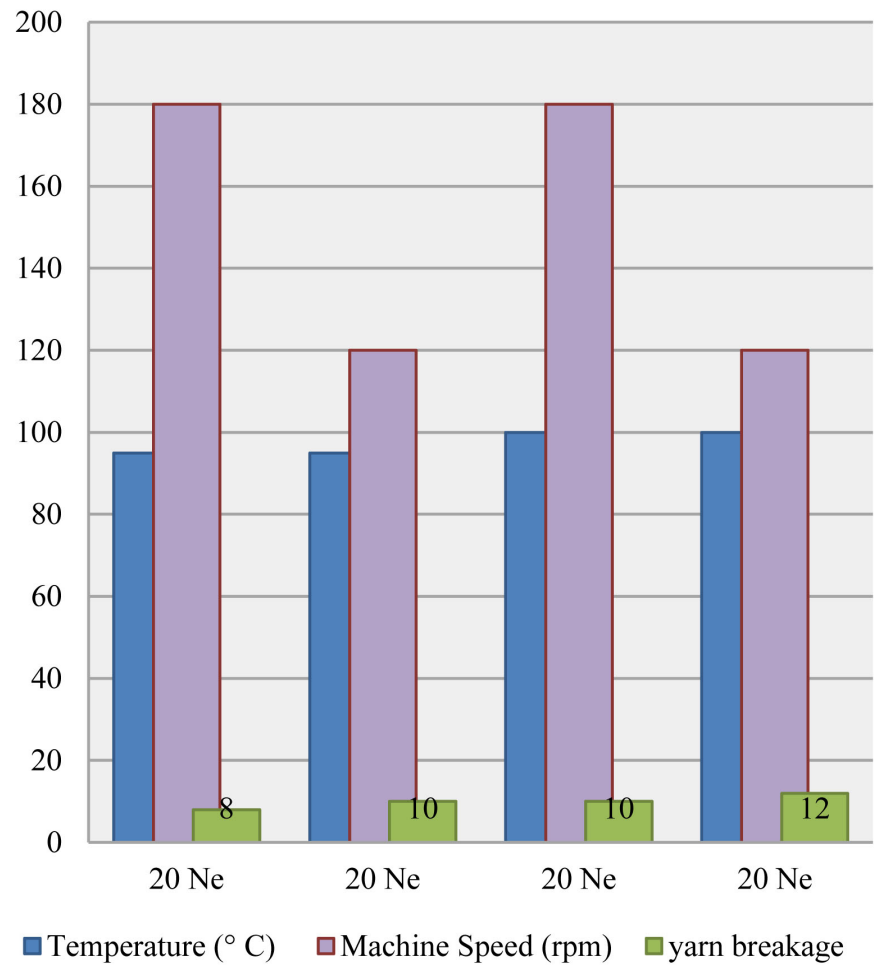

Figure 2. Weaving construction for yarn count $20 \mathrm{Ne}$. 


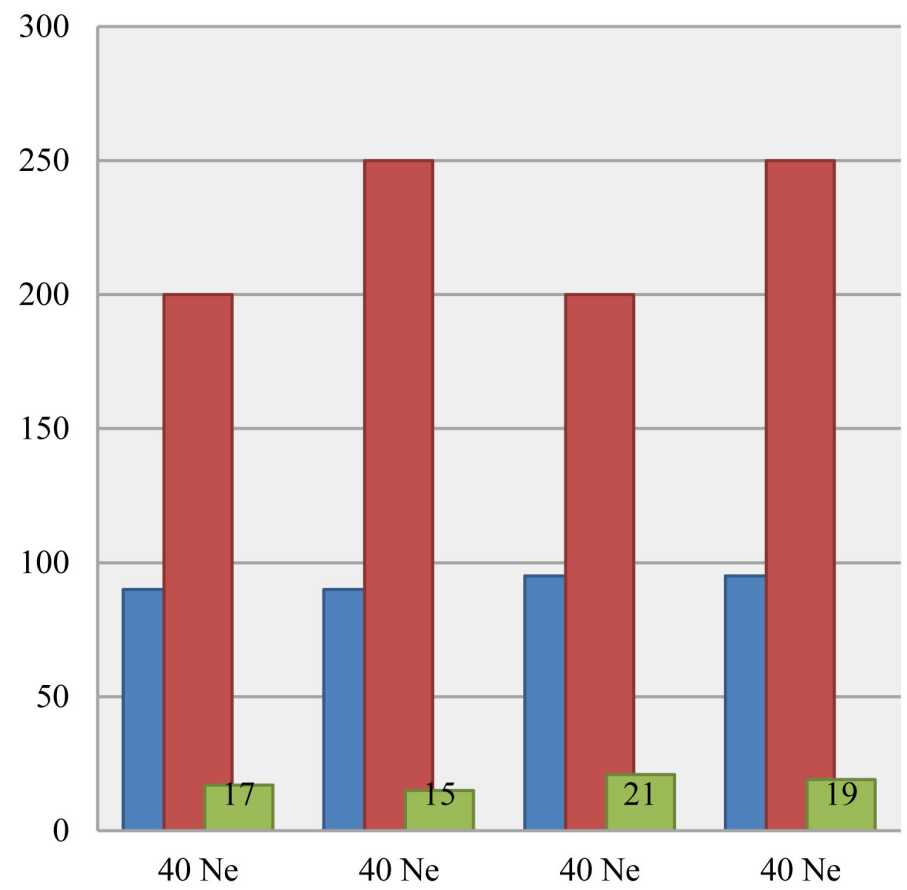

$\square$ Temperature $\left({ }^{\circ} \mathrm{C}\right) \quad \square$ Machine Speed (rpm) $\square$ yarn breakage

Figure 3. Weaving construction for yarn count $40 \mathrm{Ne}$.

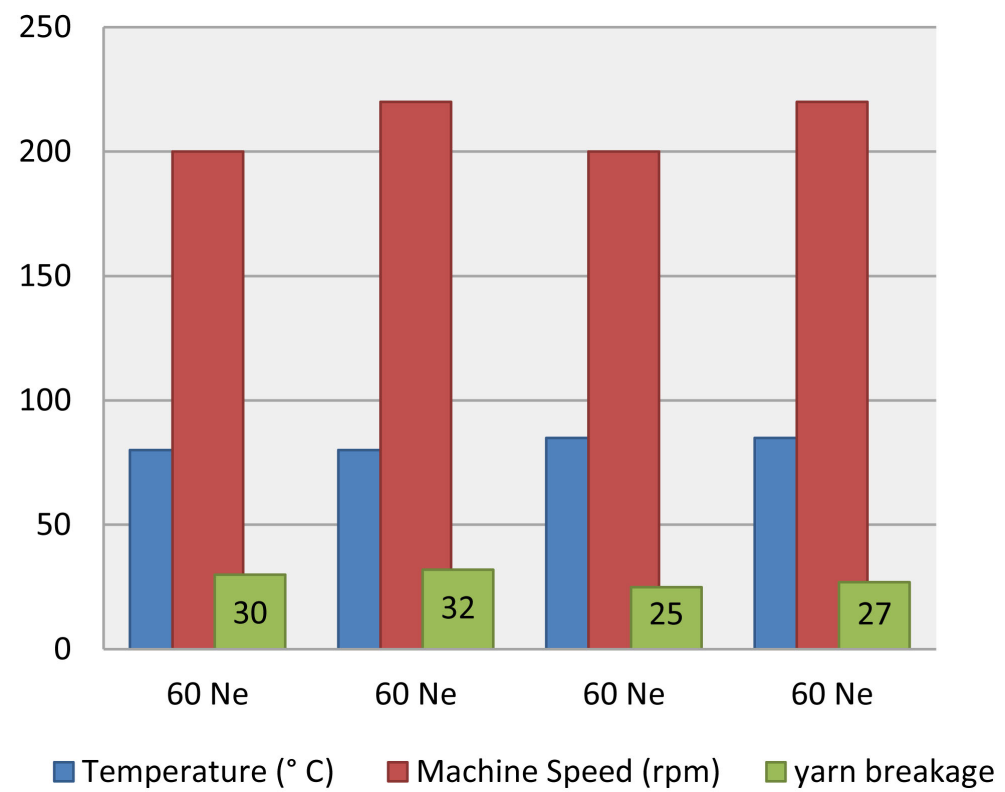

Figure 4. Weaving construction for yarn count $60 \mathrm{Ne}$.

break during weaving for $60 \mathrm{Ne}$ count cotton yarn. For $60 \mathrm{Ne}$ yarn, lower temperature results higher yarn breakage for higher moisture percentage, which condition provides higher size penetration than normal. As a result, the yarn gets swollen, and highest friction occurs during weaving. Consequently, excessive breakage occurs in the loom. The results lead to a similar conclusion where for $60 \mathrm{Ne}$ yarn; higher machine speed led to additional yarn breakage. 


\section{Conclusion}

This may be considered that a promising aspect of low-temperature condition does not afford desire dryness of yarn so, the condition provides comparatively higher moisture which affords more uniformity in size penetration. As a result, the strength of the yarn is higher in this condition and provides the least amount with the yarn breakage during weaving for coarser yarn. In conclusion, it would appear that higher machine speed supplies more yarn strength during weaving by minimizing time to get the yarn dried which condition makes the yarn uniform and moister as well as stronger. Importantly, our results provide evidence for fine yarn; lower squeezing roller pressure results in less yarn breakage for the reason that finer yarn requires less pressure to squeeze the additional size from the yarn. These findings provide a potential mechanism for weaving efficiency, which depends on numerous parameters such as size pick up percentage, adds on percentage, squeeze roller pressure, size box temperature, dryer temperature. Variable of those parameters yarn breakage rate will be reduced to a considerable extent during weaving.

\section{Conflicts of Interest}

The authors declare no conflicts of interest regarding the publication of this paper.

\section{References}

[1] Devare, D., Turukmane, R.N., Gulhane, S.S. and Patil, L.C. (2016) Effect of Yarn Stretch in Sizing on Loom Performance. International Journal of Textile Engineering and Processes, 2, 19-23.

[2] Patil, P., Turukmane, R. and Raichurkar, P.P. (2017) Comparative Analysis of Sizing Machine Parameters on Weaving Performance. International Journal on Textile Engineering and Processes, 3, 31-35.

[3] Kovačević, S. and Željko, P. (2004) Impact of Sizing on Physico-Mechanical Properties of Yarn. Fibres \& Textiles in Eastern Europe, 48, 32-36.

[4] Turukmane, R., Sujit, G. and Patil, R.B. (2019) Impact of Process Parameters on Sizing Machine Performance: A Review.

[5] El Mogahzy, Y.E. and Perkins, W.S. (1992) Effect of Creep-Related Overdrying in Sizing on Warp Characteristics and Weaving Performance. Textile Research Journal, 62, 317-324. https://doi.org/10.1177/004051759206200602

[6] Sonawane, M., Raichurkar, P.P., Patil, L.C., Kulkarni, S. and Patil, T.C. (2011) Sizing-Impact of Process Parameters on Beam Quality and Similarly on Loom Performance, Fibre to Fashion.

[7] Jia, Y.F. and Mu, Z. (2010) A New Control Strategy of Sizing Percentage Based on Analysis of Key Factors. School of Electrical Engineering and Automation.

[8] Hari, P., Behera, B., Prakash, J. and Dhawan, K. (1989) High Pressure Squeezing in Sizing: Performance of Cotton Yarn. Textile Research Journal, 59, 597-600. https://doi.org/10.1177/004051758905901007 